\title{
A brutal solidão negra no paraíso racial: a representação do negro no teatro brasileiro moderno a partir da leitura da peça Anjo negro, de Nelson Rodrigues
}

\author{
Christian Fernando dos Santos MOURA ${ }^{1}$ \\ Universidade Federal de Minas Gerais - UFMG
}

\section{Introdução}

Anjo negro é uma peça emblemática da produção teatral de Nelson Rodrigues, pois é uma das peças mais analisadas, encenadas e discutidas do autor e que provocou em sua estreia uma critica controversa quanto às qualidades do texto e da montagem. Ela foi incluída na série de textos que o próprio dramaturgo denominou de "desagradáveis" em artigo publicado em 1949 na revista Dionysos:

Com Vestido de noiva, conheci o sucesso; com as peças seguintes, perdi-o, e para sempre. Não há nesta observação nenhum amargor, nenhuma dramaticidade. Há, simplesmente, o reconhecimento de um fato e sua aceitação. Pois a partir de Álbum de família - drama que se seguiu a Vestido de noiva - enveredei por um caminho que pode me levar a qualquer destino, menos ao êxito. Que caminho será este? Respondo: de um teatro que se poderia chamar assim - "desagradável". Numa palavra, estou fazendo um "teatro desagradável", "peças desagradáveis". No gênero destas, inclui (sic, devendo-se ler-se incluo ou incluí), desde logo, Álbum de familia, Anjo negro e a recente Senhora dos afogados. E por que "peças desagradáveis"? Segundo já disse, porque são obras pestilentas, fétidas, capazes, por si sós, de produzir o tifo e a malária na plateia. (apud MAGALDI, 1981, p. 13)

O desagradável em Anjo negro é a maneira como Nelson Rodrigues tratou o tema do preconceito racial e seus efeitos sobre o comportamento humano, expondo os elos entre o mundo contemporâneo real e o mundo mítico. Segundo Magaldi (1981, p. 23): "Nelson cercou os episódios de um clima trágico, armando com a força da fatalidade. À semelhança de ciclos gregos, em que a maldição atinge a descendência, a mãe de Ismael o almadiçoa, porque ele repudia a própria cor". Dito de outra forma, o dramaturgo atualiza o mito grego antigo, no qual o herói luta contra a fatalidade trágica, transpondo-o para a realidade dos conflitos raciais brasileiro.

Anjo negro é composto em três atos e narra os conflitos de Ismael e de sua esposa Virgínia. Ele é um médico, negro, muito competente na profissão, mas portador de um grande complexo, "desde menino tem vergonha, ódio da própria cor" (RODRIGUES, 1981, p. 141), o que o torna um homem de comportamento arrivista, paranoico e violento.

\footnotetext{
${ }^{1}$ Doutorando em Artes Cênicas pela Universidade Federal de Minas Gerais - UFMG. Professor/coordenador do curso de Licenciatura em História da Universidade Bandeirante UNIBAN/Anhanguera de São Paulo, christian.moura@uol.com.br.
} 
Virgínia é uma mulher alta, bonita e branca como leite. Ao longo da trama, ela se mostra vítima da opressão da sociedade patriarcal e da violência sexual ao ser estuprada pelo marido. O rancor que Virgínia nutre em relação ao casamento torna-a uma infanticida, ela assassina um a um os filhos gerados da união com o negro, além de traí-lo com o cunhado.

Ismael quando era criança viveu com a mãe, o padrasto italiano e o irmão de criação, Elias, descrito como um vagabundo e a quem Ismael cegou na infância por sentir inveja de ser ele branco e bonito. Nada se sabe sobre o pai biológico de Ismael ou outros laços familiares. O dramaturgo escreve que Ismael na mocidade "não bebia cachaça porque achava pinga bebida de negro" (RODRIGUES, 1981, p. 141), nunca se permitia ser atraído por mulheres negras e tinha o desejo de possuir uma mulher branca. Estudou muito para ser mais que o homem branco, formou-se em Medicina, tirou da parede da casa um quadro de São Jorge, jogando-o pela janela "por que achava que era santo de preto" (Idem, p. 24). Certa vez, Ismael desapareceu de casa depois de acusar a mãe pelo fato de ter nascido negro.

A cor da pele funciona como uma sina terrível e o motor de arranque para a ação do personagem. A ação dramática revela o conflito principal do protagonista, obter sucesso na vida a qualquer custo e para isso ele renega a própria cor e deseja ser branco. O desejo de Ismael sobrepõe-se ao grau da liberdade de suas ações. Nelson Rodrigues demonstra que entre as normas morais e os desejos do negro emerge um mundo intenso de vontades proibidas e de impulsos que o levam à perversão, ao incesto e aos crimes hediondos.

\section{Texto e contexto}

A peça foi escrita em 1946. Naquela época, a ideia da ausência de preconceito racial confrontava-se com a situação do negro na estrutura social brasileira. Por exemplo, como registrou Costa Pinto (1998, p. 247), os comerciantes da rua Direita, na cidade do Rio de Janeiro, "tentaram proibir que pessoas de cor se concentrassem naquela via pública aos sábados à tarde, alegando que com isso tinham prejuízo, pois a presença de pretos afugentava a freguesia branca, de maior poder de compra”.

Nas ciências sociais, a discussão sobre o preconceito racial contra o negro no Brasil ganhou maior importância quando nos anos de 1950 a Organização das Nações Unidas para a Educação, a Ciência e a Cultura (UNESCO) amparou uma série de investigações sobre as relações raciais no Brasil. O objetivo da UNESCO era fazer da experiência sócio- 
racial brasileira, vista como harmoniosa, um exemplo à agenda antirracista elaborada pela organização durante o pós Segunda Guerra² .

No teatro, a incursão da personagem negra na literatura dramática nacional foi problematizada em 1944 com a criação do Teatro Experimental do Negro (TEN) idealizado por Abdias do Nascimento, também na antiga Capital Federal do país. ${ }^{3}$ Para Costa Pinto (1998, p. 246), originalmente, o TEN surgiu como uma reação contra a insuficiência da presença do negro nos palcos brasileiros, ou contra a presença apenas em papéis de segunda categoria, geralmente bufões ou ridículos, que assim teatralizavam a posição socialmente subalterna do negro na estrutura social, o que a trupe de artistas não desejava reproduzir.

No fluxo renovador da cena local, Nelson Rodrigues já havia lançado o marco delimitador para a história do teatro brasileiro com o grupo Os Comediantes e a encenação de Vestido de noiva, em 1943, sob a direção de Ziembinski, no Teatro Municipal do Rio de Janeiro. Segundo os estudiosos defensores de uma linha evolutiva da história do teatro brasileiro, a produção de Vestido de noiva teria equacionado, pela primeira vez, a indispensável tríade autor, encenador e elenco. (GUINSBURG et al., 2006, p. 185)

Sobre o enredo e a encenação de Vestido de noiva, Cacciaglia (1986, p. 109) descreve:

Era a primeira vez que se passava das normais histórias ambientadas na sala de visitas para a realidade dilacerante do subconsciente e da memória. Nelson Rodrigues, valendo-se das intuições pós-freudianas, consegue criar um texto desagradável, portador de uma carga insuportável de angústia, dilacerante para o autor, os intérpretes e o espectador. Protagonista do drama é uma pobre mulher, Alaíde, deprimida e aniquilada por uma briga com a irmã por causa de problemas conjugais. Sai de casa e é atropelada por um automóvel que continua em sua corrida. A ação desenrola-se nas últimas horas de vida da mulher, em três planos: o da realidade (a operação por que está passando), o da memória (o passado da protagonista) e o do inconsciente (os sonhos e a alucinação). Assim, durante os três atos da peça desenrolam-se paralelamente duas histórias, as de Alaíde, de seu marido e da irmã, e a história de amor romanesca de Madame Clessi por um belíssimo adolescente, que a protagonista lera por acaso num jornal. $\mathrm{Na}$ memória e na alucinação da moribunda os dois fatos se fundem e o jovem amado por Madame Clessi aparece com os traços do marido. O final, com a sobreposição da marcha fúnebre e com a marcha nupcial, faz prever um casamento entre o viúvo de Alaíde e a irmã.

\footnotetext{
${ }^{2} \mathrm{O}$ desejo da instituição era "organizar no Brasil uma investigação sobre contatos entre raças ou grupos étnicos, com o objetivo de determinar os fatores econômicos, sociais, políticos, culturais e psicológicos favoráveis ou desfavoráveis à existência de relações harmoniosas entre raças e grupos étnicos". (UNESCO, 1950, p. 40 apud COSTA PINTO, 1998, p. 18).

3 Abdias do Nascimento (1914-2011) foi animador cultural, artista plástico, ensaísta, dramaturgo, poeta e político. Um intelectual ligado às questões do negro e da defesa dos direitos humanos. Nelson Rodrigues foi amigo de Abdias e um companheiro e entusiasta do Teatro Experimental do Negro.
} 
Anjo negro foi levada à cena pela primeira vez no Teatro Fênix no Rio de Janeiro, em 2 de abril de 1948, após ter sido interditada pela censura federal por ser considerada um "ponto de partida para uma luta de raça, com o intuito de engendrar ódios e desordens sociais" (RIBEIRO, 1948). A primeira montagem contou com a participação da experiente atriz Itália Fausta, teve a direção do polonês Zbigniew Ziembinski e a produção de Sandro Polloni, núcleo do futuro Teatro Popular de Arte - TPA (da Cia Maria Della Costa).

O enredo é marcado por inovações na construção da personagem negra. No Brasil até os anos 1930, foi especialmente através da dança, do canto e do corpo que a personagem negra se apresentou no teatro brasileiro. Na visão de Bastide (1983, p. 146), o teatro negro "surge sob a forma do negro "musical", do negro sem problemas, do negro dependente ou místico", ainda carregando o legado escravista. Reitera o autor (Idem, ibidem):

Enquanto o teatro tradicional afro-brasileiro, o único em que o negro podia encontrar sua autenticidade, era um teatro corporal que só transmitia sua mensagem por intermédio da dança, do gesto, o teatro dos brancos se apresentava sob a forma de discurso. Ora, o discurso (o período abolicionista já tinha demonstrado) possuía mais força convincente do que a linguagem puramente corporal; e isso tanto mais que, como a linguagem corporal do branco, a comunhão das raças só dificilmente poderia acontecer. Diante dessa dificuldade de comunicação através dos sambas, dos candomblés, até mesmo da umbanda (da qual já dissemos que, tragicamente, só reconcilia as raças retomando a imagem estereotipada do negro bom escravo, não do negro revoltado), só restava aos novos intelectuais negros uma saída: retomar dos brancos o "discurso" sobre os negros para inverter seus termos e instituir assim o único diálogo que poderia se tornar autêntico; em suma, era preciso criar um teatro negro no mesmo tipo que branco, quer dizer, como linguagem vocal e voltado a uma práxis política.

O preconceito racial que Ismael sofre não o transforma num personagem caricato, muito menos o leva a recorrer ao diálogo com os símbolos ou elementos de uma cultura afro-brasileira (samba, macumba, capoeira). Ismael é um homem negro, mas é, sobretudo, um homem ele tem os defeitos e qualidades inerentes à condição humana.

As possibilidades sociais e históricas do negro como Ser humano não são limitadas pela a cor de sua pele, o fato de ser negro não lhe retira e nem minimiza suas potencialidades humanas de amar, mentir, matar, sofrer e trair. Ele é um homem negro que enfrenta a discriminação racial como vítima, mas também como algoz da sua condição e da sua fortuna.

Em abril de 1947, quando ainda se pretendia que a peça fosse encenada no Teatro Municipal do Rio de Janeiro, Nelson Rodrigues escreveu na revista O Cruzeiro:

O negro Ismael - o herói - é belo, forte, sensível e inteligente. Esse desfile de qualidades não é tudo, porém. Se ele fosse perfeito, cairíamos no exagero inverso e 
faríamos um negro tão falso quanto o outro. Ismael é capaz também de maldades, de sombrias paixões, de violências, de ódios. Mas, no ato de amor ou de crueldade, ele é, será sempre um homem, com dignidade dramática, não um moleque gaiato. (CASTRO, 1992, p. 203)

A história é sobre o preconceito racial no Brasil, mas os personagens da trama possuem conflitos universais presentes em todas as "raças". ${ }^{4}$ Nesse sentido, seguindo a interpretação filosófica proposta por Paul Ricouer (1987), considera-se importante numa primeira etapa do processo interpretativo a descrição das estruturas internas de Anjo negro. Como explica Santos (2005, p. 16):

Essa descrição procura esmiuçar a obra em sua composição, na lógica imanente da sua escrita, como o texto é organizado no encadeamento da intriga, nas ações, nas características das personagens e nas indicações espaciais e temporais. É um mapeamento da estrutura do texto para localizar as partes e a forma com que a escrita organiza o mundo da obra.

Dito de outra maneira, a análise descritiva do enredo e a caracterização das personagens de Anjo negro auxiliam para a composição e explicação das ações e para demonstrar como as questões do preconceito e discriminação racial são fatores significativos para a tessitura da trama.

\section{Ação, organização e estruturação}

A primeira montagem de Anjo negro fez temporada de um mês e meio no Rio de Janeiro e, em seguida, viajou para São Paulo, sendo um sucesso em sua época. Mas, apesar do esforço do dramaturgo em notabilizar a presença do negro no teatro brasileiro, o protagonista da peça não foi interpretado por um ator negro, como queria Nelson, mas pelo branco Orlando Guy com rosto brochado de preto. Parafraseando Castro (1992, p. 204): não se tratava de fazer um teatro de "tese", classificação que provocava urticárias no dramaturgo, mas Nelson se queixou de que o ator pintado, por melhor que fosse, não tinha a "autenticidade racial e cênica" de um negro de verdade. E a história, que teria mais impacto em "preto-e-branco", ficou na sombra dos efeitos plásticos da produção: o glorioso "technicolor" da cenografia de Sandro Polloni e a condução artística de Ziembinski (CASTRO, 1992, p. 204).

Vejamos o registro de Castro (Idem, p. 204):

\footnotetext{
4 “...embora a raça não consista numa realidade biológica, seu uso enquanto categoria analítica em pesquisas científico-sociais se justifica por ainda constituir uma realidade social, com efetivas e reais consequências sobre a vida dos indivíduos e coletividades. (TAVOLARO, 2012)
} 
Escrever uma peça sobre negros era uma antiga ideia sua, diria Nelson depois, mas apelos mais urgentes o tinham feito adiá-la. O que finalmente o motivara a sentarse e escrever fora o seu convívio com Abdias do Nascimento, o jovem ator com quem ele se encontrava diariamente no "Vermelhinho", o café dos escritores e jornalistas na Cinelândia, em frente a ABI.

Mexendo o cafezinho para que ele esfriasse, Nelson dizia a Abdias:

"Nos Estados Unidos, o negro é caçado a pauladas e incendiado com gasolina. Mas no Brasil é pior: ele é humilhado até as últimas consequências".

A construção do personagem de Ismael para além de ter sido inspirada no convívio com Abdias do Nascimento pautava-se também na própria figura do líder do TEN, "Ismael, no dizer de Castro (1992, p.203), era um preto como Abdias do Nascimento, para quem foi escrita a peça: doutor de anel no dedo e orgulhoso de sua raça, mas com todos os defeitos do ser humano, branco, amarelo ou furta-cor".

Na peça de Nelson Rodrigues, o negro tornou-se um doutor renomado e casou-se com a jovem branca Virgínia, órfã que morava com a tia viúva, "fria e má" (RODRIGUES, 1981, p. 143), e as cinco primas solteironas, com exceção da caçula, de casamento marcado com um belo rapaz. Virgínia amava o noivo da prima. Uma noite em que ela estava sozinha e o noivo chegou mais cedo do que de costume, os dois deram vazão ao desejo mútuo. Tia e prima flagram a cena desse beijo. O noivo foge, para sempre, Virgínia é presa no quarto pela tia, e a prima enforca-se no banheiro.

Ismael, clínico da família e que há muito tempo desejava sexualmente Virgínia, chega à casa. De madrugada, a viúva, nutrida do sentimento de vingança pelo suicídio da filha, ordena a Ismael que possua a sobrinha. Depois disso, ele compra a residência e expulsa tia e primas. O estupro é narrado no ATO II (Idem, p. 144):

VIRGÍNIA - E eu ali. De noite, Ismael veio fazer quarto. Era o único de fora, ninguém mais tinha sido avisado. De madrugada, senti passos. Abriram a porta era ele mandado pela minha tia. Eu gritei, ele quis tapar minha boca - Gritei como uma mulher nas dores do parto... (muda de tom) Se pudesse ver, eu te mostraria.

Passados oito anos, marido e mulher vivem isolados, mantêm uma relação ambígua e tortuosa que combina os sentimentos de afeição e ódio, aversão e desejo, cinismo e cumplicidade. Ismael submete Virgínia a um cárcere privado prolongado, horrorizado com a possibilidade de ela relacionar-se com outro homem, ainda mais se branco. O médico, "obsessivo" e paranoico, constrói um alto muro em torno da casa e deixa de clinicar para ter mais tempo de vigiar a mulher. Ela, encarcerada em sua própria casa, mantém pelo esposo um misto de atração e repulsa e cria nojo pela cor negra. Não aceita a prole mestiça 
e, para vingar-se do marido, mata os filhos negros dessa união conflituosa. Vejamos (Idem, p. 144):

ISMAEL - Um por um. Este último, o de hoje, tu mesma o levaste, pela mão. Não lhe disseste uma palavra dura, não o assustaste; nunca foste tão doce. Junto do tanque, ainda o beijaste; depois, olhaste em torno. Não me viste, lá em cima, te espiando... então, rápida e prática - já tinha matado dois - tapaste a boca do meu filho, para que ele não gritasse... Só fugiste quando ele não se mexia mais no fundo do tanque.

VIRGÍNIA (feroz, acusadora) - Então, por que não gritou? Por que não impediu? ISMAEL (cortante)- Mas é verdade?

VIRGÍNIA (espantada) - É.

ISMAEL - Aos outros dois você deu veneno...

VIRGÍNIA (hirta) - Sim.

ISMAEL - Porque eram pretos.

VIRGÍNIA (abandonando-se) - Porque eram pretos. (com súbita veemência) Mas se sabias, por que não impediste?

Ismael testemunha os crimes da mulher, mas confessa não tê-la impedido porque isso os unia ainda mais e porque seu desejo aumentara ao sabê-la assassina. Tais crimes ligam visceralmente o casal. Eles realizam, continuamente, o mesmo rito trágico desde o início de suas núpcias: conceber e assassinar a sua prole.

No introito da peça, percebe-se a questão central do enredo. As consequências sociais e psíquicas causadas pela discriminação racial e o preconceito. O autor apresenta a casa de Ismael, onde ocorre o velório de um menino negro. "A casa não tem teto, para que a noite possa entrar e possuir os moradores. Ao fundo, grandes muros que crescem à medida que aumenta a solidão do negro" (RODRIGUES, 1981, p. 125). De pé, estão: Ismael, rígido, velando o caixão de anjo, o grande negro, durante toda a representação, usará um terno branco, de panamá, engomadíssimo, sapatos de verniz; Virgínia veste luto fechado; dez senhoras negras também velam a criança e exercem um papel profético, comentam sobre o menino morto e o casal:

SENHORA (doce) - Um menino tão forte e tão lindo!

SENHORA (patética) - De repente morreu!

SENHORA (doce) - Moreninho, moreninho!

SENHORA - Moreno, não. Não era moreno!

SENHORA - Mulatinho disfarçado!

SENHORA (polêmica) - Preto!

SENHORA (polêmica) - Moreno!

SENHORA (polêmica) - Mulato!

SENHORA (em pânico) - Meu Deus do Céu, tenho medo de preto! Tenho medo, tenho medo!

SENHORA (enamorada) - Menino tão meigo, educado, triste!

SENHORA (encantada) - Sabia que ia morrer, chamou a morte!

SENHORA (na sua dor) - É o terceiro que morre. Aqui nenhum se cria! 
SENHORA (num lamento) - Nenhum menino se cria!

SENHORA - Três já morreram. Com a mesma idade. Má vontade de Deus!

SENHORA - Dos anjos, má vontade dos anjos!

SENHORA - Ou é o ventre da mãe que não presta!

SENHORA (acusadora) - Mulher branca, de útero negro!

SENHORA (num lamento) - Deus gosta das crianças. Mata as criancinhas!

Morrem tantos meninos!

TODAS - Ave-maria, cheia de graça... (perde-se a oração num murmúrio

ininteligível) Padre-nosso que estais no céu... (perde-se o resto num murmúrio ininteligível).

SENHORA (assustada) - E se afogou num tanque tão raso!

SENHORA - Ninguém viu!

SENHORA - Ou quem sabe se foi suicídio?

SENHORA (doce) - Mas seria tão bonito que um menino se matasse!

SENHORA - O preto desejou a branca!

SENHORA (gritando) - Oh! Deus mata todos os desejos!

TODAS - Maldita seja a vida, maldito seja o amor!

(Cessam todas as vozes. Ismael vem olhar o rosto do filho. Em cima, no quarto, Virgínia se ajoelha. Na parte de fora aparece um jovem vagabundo; caminha, indeciso, com um bordão. Logo se percebe que é um cego, cabelos claros e anelados; seu rosto exprime uma doçura quase feminina. Surgem, em seguida, quatro negros, que se espantam com a presença do cego. Negros seminus, chapéu de palha, fumando charuto.) (Idem, pp. 125-6).

No desenrolar da trama, o homem branco e cego que chega à residência para o enterro do menino negro é Elias, o irmão postiço de Ismael. Certa vez, Elias, o caçula, estava doente dos olhos e Ismael é quem o tratava. Por inveja, Ismael trocou os medicamentos, causando em Elias uma cegueira irreversível. O moço acredita ter sido um acidente, por isso volta a procurar o irmão para transmitir-lhe mensagem da mãe moribunda: “...Ismael, tua mãe manda sua maldição” (Idem, p. 130). Elias é o portador da desgraça, a aversão que Ismael sente pela própria cor é o elemento responsável pelo vaticínio profético de sua mãe: o negro irá sofrer por odiar sua própria cor.

No tempo entre o enterro e a hora em que Ismael chega a casa, Virgínia toma conhecimento da presença de Elias, suborna a empregada negra e atrai o cunhado para seu quarto. Virgínia deseja ter um filho branco, que não seja fruto de uma relação violenta; para isso seduz e usa o rapaz, que se apaixona por ela de maneira arrebatadora. Os dois se beijam, fazem sexo e Virgínia engravida. $\mathrm{Na}$ sequência, ela pede para que Elias desapareça e justifica que, se o marido soubesse o que aconteceu, mataria os dois.

As tias e as primas chegam atrasadas para o velório e o enterro, mas em tempo de presenciar o cego saindo do quarto de Virgínia. A tia ameaça:

TIA - Ismael, sim. Vai saber que tens um amante...

VIRGÍNIA (num lamento) - Não é amante!

TIA - Um amante que não te conhecia e que tu não conhecias. Um amante que mandaste chamar, que seduziste, que trouxeste pela mão até teu quarto. 
Direi a ele, a teu marido! (Idem, p. 145).

Ismael volta para casa; Virgínia diz que está esperando um filho dele, promete que esse não morrerá como os outros e pede ao marido que não dê ouvidos às intrigas e calúnias da tia e que a expulse da casa. Ismael acata aos conselhos da esposa e escorraça a velha da casa. A viúva, antes de ser escorraçada pelo negro, denuncia que Virgínia teve relações sexuais com Elias e o filho que a adúltera espera é, na verdade, do cunhado. Ismael enfurece-se e diz que vai matar o irmão, mas ao saber que Elias fugiu, ele promete assassinar o filho da traição, caso nascesse um menino, pois assim poderia vingar-se da morte dos filhos assassinados por Virgínia. Ela desespera-se com as ameaças do marido, revela seu verdadeiro desejo pela maternidade, diz ser apenas vítima da violência masculina e num ato de loucura entrega o amante para a morte. O negro recalcado irá se tornar um assassino:

ISMAEL (como se quisesse convencê-la) - Já que este homem fugiu - pagará o teu filho, o filho dele.

(Virgínia perde a cabeça; sua incoerência é absoluta)

VIRGÍNIA - Meu filho, não. Meu filho não é culpado de nada, Ismael. Eu não amo este homem. Se eu o chamei, foi por causa do filho, para ter o filho... Teu irmão não me importa. E não é puro, não é inocente... Se disse isso, foi para te enganar, pensando que assim sentirias menos. Mas ele só sabe amar como você, como qualquer outro - Fazendo da mulher uma prostituta... (num esforço supremo para convencer o marido) Pois se até eu fiquei com ódio dele, e de mim (histérica) com ódio da cama, da fronha, do lençol, de tudo!

(Mergulha o rosto nas mãos, numa crise de lágrimas).

ISMAEL - Acredito.

VIRGÍNIA (erguendo o rosto) - Então, perdoas meu filho?

ISMAEL - Não.

VIRGÍNIA - E se eu te desse uma prova? Se provasse que este homem não é nada para mim? (muda de tom, lenta) Eu menti quando disse que ele fugira. Está lá embaixo, no quarto, à minha espera... Pertinho daqui...

ISMAEL (numa alegria selvagem) - Lá embaixo, ainda está aî? Não fugiu? (Rápido, apanha um revólver. Virgínia acompanha fascinada todos os seus movimentos.)

VIRGÍNIA (indo ao seu encontro) - Ele é quem deve pagar, e não meu filho. Ele, sim, que me possuiu...

ISMAEL - Não sofrerás, se ele morrer?

VIRGÍNIA - Eu, não! Pois até quero, se fui eu que disse que ele ainda estava aí!... (RODRIGUES, 1981, pp. 164-5).

As confissões de Virgínia parecem não fazer eco nos ouvidos do marido. Ele acredita que ela não seja culpada pela traição e que nada sente pelo cunhado, mas para ter certeza da inocência da esposa, Ismael ameaça matar o filho branco que ela já leva no ventre. Virgínia, invadida pela obsessão de dar à luz a um filho branco, cumpre o rito da traição. 
No final do segundo ato, Ismael manda Virgínia chamar Elias, que ainda encontrava-se escondido na casa. O marido aponta o revólver contra o cego. Elias, que não sabe da presença de Ismael, declara-se apaixonado por Virgínia, mas antes de ser correspondido é morto com um tiro a queima-roupa na altura da cara.

A vontade dos indivíduos não resolve as relações. Ismael contraria as expectativas de ações típicas de personagens machistas e paranoicas. E ao invés de querer assassinar a mulher, deseja eliminar o filho branco que ela espera.

Os anseios do homem negro são guiados pelo o ódio e a rejeição ao outro, o branco. Para Moutinho (2004, p. 162), o enlouquecimento e ódio de Ismael, "quando descobre a traição e percebe que a esposa não esquecerá o "amor inocente" experimentado com seu irmão branco," repousam não no desejo sexual que ele sente pela mulher, e sim, nos rancores que o mesmo sente por causa do racismo brasileiro.

No primeiro quadro do último ato, a narrativa dá um pulo temporal. Informa o autor: "Passaram-se dezesseis anos e nunca mais fez sol" (RODRIGUES, 1981, p. 169). Da relação entre Virgínia e Elias, em vez de um homem, nascera uma filha: a branca e linda Ana Maria.

SENHORA - Graças a Deus, todo-poderoso...

SENHORA - Há quinze anos nasceu uma filha.

SENHORA - E branca.

SENHORA - Não um menino, mas uma menina.

SENHORA - De peito claro.

SENHORA - Nasceu nua, e por isso o pai disse logo: "É menina."

SENHORA - Porque nasceu nua.

SENHORA (em conjunto) - Virgem Maria... Maria Santíssima...

SENHORA - Há 16 anos que não faz sol nesta casa. Há 16 anos que é

noite.

SENHORA - E as estrelas fugiram.

SENHORA - A menina viveu, hoje é mulher.

SENHORA (num lamento) - Hoje é mulher.

SENHORA - Oh, Deus! Poupai Ana Maria do desejo dos homens

solitários que, por isso, desejam mais!...

SENHORA - E não saiu mais enterro.

SENHORA - Sem flor.

SENHORA - Daqui não saiu... (Idem, p. 170)

Na continuação, Ismael e Virgínia discutem sobre o estupro de uma moça por um homem negro de seis dedos que aconteceu nas vizinhanças. Ismael diz a Virgínia que, se fosse ela no lugar da violentada, ele nada faria e ficaria ao lado da filha olhando ela ser estuprada, pois ele só ama uma mulher no mundo: Ana Maria. Virgínia confessa ter ciúmes da garota e ameaça contar para a filha que Ismael não é branco e nem é seu pai; que ele 
matou seu pai biológico e a cegou quando bebê. Por um momento, Ismael ameaça expulsar a esposa de casa, mas depois de ouvir seus argumentos, volta atrás, autorizando Virgínia a contar toda a verdade para Ana Maria.

Durante três dias, Virgínia tenta, em vão, convencer a filha sobre as mentiras de Ismael e a convida a fugir com ela para um lugar onde só houvesse homens sensíveis, que soubessem como tratar bem a uma mulher. Ana Maria diz que não acredita numa única palavra da mãe; e que não se importaria mesmo que tudo fosse verdade; confessa-se mulher, que perdeu a virgindade com Ismael e que o ama.

Enquanto isso, Ismael construiu um mausoléu de vidro para ele e Ana Maria se isolarem do mundo e do desejo dos outros homens; ele diz amar Ana Maria como mulher e acusa a esposa de odiar os homens negros. Virgínia declara a Ismael: "Tive ódio e loucura por ti" (Idem, p. 188), que durante o tempo em que ela passou com Ana Maria, descobriu que já amava negros desde criança, quando viu quatro negros carregando piano na rua da sua casa, no norte, e considera que a filha só amava Ismael por não saber que ele era um "negro hediondo". Discute o casal no último quadro:

VIRGÍNIA (escarnecendo) - E pensa que você é branco, louro! (triunfante) Se ela soubesse que és preto!... (muda de tom) Ela te ama porque acha que é o único branco... Ama um homem que não é você, que nunca existiu... Se ela visse você como eu vejo - se soubesse que o preto é você (ri ferozmente) e os outros não; se visse teus beiços, assim como são, ela te trocaria, até, por esse homem de seis dedos... (Agarra-se mais ao marido, envolve-o.)

VIRGÍNIA - Agora, eu não!... Eu te quero preto, e se soubesses como te acho belo, assim como os carregadores de piano!... De pés descalços, cantando!

ISMAEL - És meiga como uma prostituta!

VIRGÍNIA - Sou, não sou?

ISMAEL (apaixonado) - E ela, não! (com rancor) Ela se dá como o pai possuía com tanta pureza!... (exalta-se) Não seria como tu... Não teria o medo que sempre tiveste... Não gritaria... Ama sem sofrimento e sem pavor... E não sabe que eu sou preto, (tem um riso soluçante) não sabe que sou um "negro hediondo", como uma vez me chamaram... Só me ama porque eu menti - tudo o que eu disse a ela é mentira, tudo, na verdade! (possesso) Não é a mim que ela ama, mas a um branco maldito que nunca existiu!

VIRGÍNIA - Vem comigo, vem!

ISMAEL (espantado) - Mas e ela? Você não compreende que ela não deixa? Que sempre estará entre nós?

VIRGÍNIA - Eu sei como fazer - para que ela fique tranqüila... (resoluta)

Vai chamar minha filha. Traz a minha filha. Diz que é um passeio. E quando chegar aqui, eu quero que tu a beijes como teu filho que morreu, no tanque... (Idem, p. 190).

Na sequência, Ismael vai buscar Ana Maria. A garota conta sobre o que a mãe disse a seu respeito; Ana Maria pressente o que está por acontecer e pede a Ismael que a proteja das maldades da mãe e declara: "És o único homem que existe” (Idem, p. 191). 
Virgínia aparece e abre a porta da sepultura para que Ismael conduza a menina. Os dois encerram a jovem cega no túmulo de vidro e depois vão para a cama. O autor deixa implícita a ideia do presságio da concepção de mais um novo filho. As senhoras negras se postam em semicírculo em torno da cama de solteira de Virgínia e da cama do casal formando um coro:

SENHORA - Ó branca Virgínia!

SENHORA - (rápido) - Mãe de pouco amor.

SENHORA - Vossos quadris já descansam.

SENHORA - Em vosso ventre existe um novo filho!

SENHORA - Ainda não é carne, ainda não tem cor!

SENHORA - Futuro anjo negro que morrerá como os outros!

SENHORA - Que matareis com vossas mãos!

SENHORA - Ó Virgínia, Ismael!

SENHORA (com voz de contralto) - Vosso amor, vosso ódio não têm fim neste mundo!

TODAS (grave e lento) - Branca Virgínia...

TODAS (grave e lento) - Negro Ismael...

(Ilumina-se a cama de solteira, cujo aspecto ainda é o mesmo da noite em que Virgínia foi violada. Depois tudo escurece e só resta iluminado o túmulo de vidro. Vê-se a silhueta de Ana Maria, no frenético e inútil esforço de libertação. Por fim, cansada do próprio desespero, ela se deixa escorregar, em câmara lenta, ao longo do vidro. Fica de joelhos, os braços em cruz; parece petrificada nesta posição. É a última imagem da jovem cega.)

FIM DO TERCEIRO E ÚLTIMO ATO. (Idem, p. 192).

\section{A personagem negra, forma e conflito.}

A formalização da personagem negra em Anjo negro revela um paradoxo entre os enunciados do conflito e a forma de sua representação. De acordo com o Dicionário de Teatro de Patrice Pavis (2005, p. 332), na dramaturgia clássica ocorre que uma personagem em suas ações ou falas seja reconhecida por outra, o que desencadeia o conflito, desarmando-o no caso da comédia ou concluindo-o trágica ou magicamente. Seguindo os preceitos do drama clássico, esperar-se-ia que, para a construção do conflito racial vivido por Ismael, Nelson formalizasse um personagem em condições de perceber seu conflito em busca de sua superação.

Mas, os reveses vividos por Ismael não o fazem um negro resignado ou revoltado. O objeto do preconceito racial não leva o autor a construir uma personagem negra autoconsciente do problema racial. Nesta tragédia, o que move o protagonista é a ambição pessoal. As ações do personagem não seguem em direção às necessidades coletivas e éticas do mundo, mas no sentido das suas demandas individuais. Ismael é um homem que tem o desejo de alcançar bom êxito na vida a todo custo e essa cobiça traça sua 
trajetória rumo a exaltações, sucessos e agruras na vida. Na explicação de Ferreira (2012, p.

02) Ismael:

Renegou sua família e faz de sua esposa uma prisioneira, além de ser cruel com todos ao seu redor. Pela forma como então se manifesta, fala e atua, Ismael assemelha-se a um indivíduo errante, desejante e sofredor. Age desta forma pela vergonha de sua cor, mas também é bem sucedido na vida pelos mesmos motivos. Assim, desenvolve a trajetória de um herói trágico, transpondo-se da fortuna ao infortúnio no decorrer da peça.

Ismael tornou-se médico e casou-se com uma mulher branca, mas isso não lhe trouxe satisfação. Se “a ação só se deterá quando o personagem tiver encontrado seu estado original ou atingido um estágio no qual não haja mais conflito" (PAVIS, 2005, pp. 287), em Anjo negro o desenlace da trama não objetiva o fim do conflito de Ismael. Uma das mulheres negras do coro afirma: "Futuro anjo negro que morrerá como os outros!". Por mais que o personagem lute, não conseguirá fugir de seu destino, Ismael nunca "embranquecerá" por inteiro, seus filhos com a mulher branca nascerão com a sua cor e o lembrarão para sempre de sua origem social e racial.

Na sociedade brasileira o sujeito negro, quando não tenta mais transformar o corpo negro em corpo branco, "contenta-se em renegar o estereótipo do comportamento negro, copiando e assumindo um estereótipo de comportamento que pensa ser exclusivo do branco e em cuja supremacia acredita" (COSTA, 1983, p. 11).

Ismael é um negro complexado por sua cor. Deseja superar as barreiras sociais impostas pelo preconceito e torna-se negro de classe média. Numa sociedade racializada entre brancos e negros como a sociedade brasileira, uma das táticas possíveis para o sujeito pertencente ao grupo racial estigmatizado ou marginalizado é a adoção dos valores do grupo racial detentor do poder econômico. Ismael repudia sua origem social e racial, deseja compensar sua cor com os predicados da brancura. Para Costa (Idem, p. 04)

o sujeito negro oprimido, os indivíduos brancos, diversos em suas efetivas realidades psíquicas, econômicas, sociais e culturais, ganham uma feição ímpar, uniforme e universal, a brancura. A brancura detém o olhar negro antes que ele penetre a falha do branco. A brancura é abstraída, retificada, alçada à condição de realidade autônoma, independente de quem a porta enquanto atributo étnico ou, mais precisamente, racial.

No dizer de Rodrigues (1968:1997, p. 201): “Não há na Terra ninguém mais só do que o nosso preto. Um esquimó tem a companhia de meia dúzia de outros esquimós. Mas a 
solidão do negro brasileiro não tem nem a companhia do próprio negro." 5 E o coro de mulheres negras sugere os reveses pelos quais passa Ismael. Elas são negras e por cumplicidade poderiam ficar do seu lado, mas ao contrário reproduzem o discurso do preconceito racial velado por convenções da sociedade brasileira.

A cor da pele aparece como uma marca para as personagens da tragédia rodriguiana, nascer moreninho, moreno, mulatinho disfarçado ou mulato significa um gradiente de cor para clarear a "raça". Aqui a "miscigenação oferece o caminho para afastar a diferença ameaçadora representada pela presença da raça e de cultura negra na sociedade" (MUNANGA, 2006, p. 129). Os filhos mestiços de Ismael com Virgínia permitiriam ao negro vislumbrar em seus descendentes a possibilidade do embranquecimento.

Mas nem o fato das crianças nascerem quase negras quase brancas garante-lhes a sobrevivência. O negro já havia tentado embranquecer a raça ao casar-se à força com uma mulher branca, mas "a tentativa de branqueamento é duplamente frustrada: os filhos de Ismael são negros como ele e, por isso, assassinados pela mãe que não suporta ver em sua descendência o reflexo do marido". (LEAL, 2008, p. 02).

Por seu turno, Ismael, ao permitir que o irmão fique em sua casa, sela seu destino. A disputa com o irmão pela mulher branca evidencia uma narrativa contra a possibilidade de através da "mistura" e do contato "inter-racial" se "embranquecer" (MOUTINHO, 2004, p. 62). A exposição dramática em relação ao preconceito racial não se dá somente nas ações e nos diálogos entre as personagens, mas também através de formas dramáticas alegóricas: os dois cegos brancos, o negro estuprador de seis dedos, o túmulo de vidro de Ana Maria. A expressão alegórica no dizer de Bosi (2000, p. 52) "abre o intervalo entre a forma sensível e a ideia". E as alegorias em Anjo negro expressam os limites e as influências do preconceito sobre a mente humana.

\section{Considerações finais}

Anjo negro é rasgado por diálogos e alegorias afiadas que dilaceram o mito da democracia racial brasileira e problematizam as questões da representação da identidade negra no cenário nacional. Percebe-se uma efetiva mudança de paradigma, uma alteração qualitativa e substancial da representação do negro pelo teatro brasileiro, levando à elaboração de uma nova configuração conceitual.

\footnotetext{
5 Nelson Rodrigues escreveu novamente sobre a brutal 'solidão negra' ao afirmar que "Nunca se viu um negro de casaca, nunca se viu uma estátua equestre de negro, nunca se viu um grã-fino negro..." Essa declaração foi dada em carta resposta ao dramaturgo Plínio Marcos quando da polêmica racial acerca do ator Sérgio Cardoso, que interpretou um negro na novela $A$ cabana do Pai Tomás da TV Globo, em 1969. O ator foi pintado, usando peruca e rolhas no nariz para ficar parecido com um negro. (BRANCO, 2011).
} 
A história revela acerca da constituição da personagem negra a possibilidade do negro poder ser representado em todas as suas dimensões humanas e não somente raciais. O arrivismo de Ismael explica-se em boa parte pelo preconceito racial que sofre, mas não se limita somente a essa explicação. A ânsia pela mobilidade social também define o caráter do personagem

O negro em Anjo negro procura encontrar seu lugar no mundo, nesse sentido sua busca perpassa o particular para atingir o universal. No dizer de Fanon (2008, p. 26) "O negro é um homem negro; isto quer dizer que, devido a uma série de aberrações afetivas, ele se estabeleceu no seio de um universo de onde será preciso retirá-lo". O autor à medida que fala sobre o negro brasileiro, também se afasta dele para representar o homem e faz sair o negro do lugar onde estava.

O importante é destacar que o texto de Nelson Rodrigues dialetizou as contradições do negro, apurou suas angústias e ansiedades e construiu um personagem negro com ricas possibilidades dramáticas, evitando as caricaturas ou estereótipos herdados do período da escravidão e o sentimento paternalista ao tratar a "raça" negra como outra qualquer.

\section{BIBLIOGRAFIA CITADA:}

BRANCO, Lucio Allemand. O negro é um "outro": a representação dramática do negro no Brasil a partir da polêmica racial entre Nelson Rodrigues e o seu "sucessor" Plínio Marcos. Anais do XII Congresso Internacional da Associação Brasileira de Literatura Comparada (ABRALIC), Curitiba, julho 2011.

Disponível em:

http://www.abralic.org.br/anais/cong2011/AnaisOnline/resumos/TC1174-1.pdf>. Acesso em: 27 de julho de 2012.

BOSI, Alfredo. Reflexões sobre a arte. São Paulo, Ática, 2002.

CASTRO, Ruy. O anjo pornográfico: a vida de Nelson Rodrigues. São Paulo, Cia. das Letras, 1992.

COSTA PINTO, L. A. O negro no Rio de Janeiro. Relações de raça numa sociedade em mudança. Rio de Janeiro, Editora UFRJ, 1998.

COSTA, Jurandir Freire. Da cor ao corpo: a violência do racismo. In. SOUZA, Neusa Santos. Tornar-se negro: as vicissitudes da identidade do negro brasileiro em ascensão. Rio de Janeiro, Edições Graal, 1983.

FANON, Frantz. Pele negra, máscaras brancas. Salvador, Edufba, 2008.

FERREIRA, Jaqueline Garcia; MORAES, Carlos Eduardo Mendes de. O trágico moderno: a tragédia nietžschiana na peça Anjo negro de Nelson Rodrigues. Disponível em: http://prope.unesp.br/xxi_cic/27_38103538841.pdf> Acesso em: 30 outubro 2012.

GUINSBURG, Jacó; FARIA, João Roberto; LIMA, Mariangela Alves. Dicionário do teatro brasileiro. São Paulo, Perspectiva, 2006.

LEAL, Mara Lucia Anjo negro: cor e desejo. IV ENECULT - Encontro de Estudos Multidisciplinares em Cultura, 28 a 30 de maio de 2008. Faculdade de Comunicação/UFBa, Salvador-Bahia-Brasil. Disponível em:

<http://www.cult.ufba.br/enecult2008/14654.pdf>. Consulta em 31 outubro 2012.

MAGALDI, Sábato. (Org.). Teatro completo de Nelson Rodrigues. vol. 2. Rio de Janeiro, Nova Fronteira, 1981. 
. Panorama do teatro brasileiro. São Paulo, Difusão Europeia do Livro, 1962.

NASCIMENTO, Abdias. Teatro experimental do negro: trajetória e reflexões. Estudos Avançados, São Paulo, vol.18, n.50, 2004. pp. 209-224.

RIBEIRO, Violeta. A respeito de 'Anjo Negro'. Correio da Manhã, Rio de Janeiro, 11 abril 1948. Enciclopédia Cultural da Literatura Brasileira. Disponível em: http://www.itaucultural.org.br/. Acesso em: 17 julho 2012.

RODRIGUES, Nelson Falcão. Abdias: O negro autêntico. Jornal Ultima Hora, 26 agosto 1957. In. Teatro Experimental do Negro - Testemunhos. Rio de Janeiro, GRD, 1966.

vol. 2. Rio de Janeiro, Nova Fronteira, 1981. . Anjo Negro. In: MAGALDI, Sábato (org.). Teatro completo de Nelson Rodrigues. O óbvio ululante: as primeiras significações. Rio de Janeiro, Agir, 2007.

1996. . O remador de Ben-Hur: confissões culturais. São Paulo, Companhia das Letras,

RICOUER, Paul. Teoria da interpretação. Lisboa, Ed. 70, 1987.

SOUZA, Neusa Santos. Tornar-se negro: as vicissitudes da identidade do negro brasileiro em ascensão. Rio de Janeiro, Edições Graal, 1983.

TAVOLARO, Lilia G.M. Teoria social e o (re) conhecimento da raça: dilemas e reflexões. Teoria \& Pesquisa: Revista de Ciência Política. Universidade Federal de São Carlos (UFSCar). Disponível em: <http:/ /www.teoriaepesquisa.ufscar.br>. Acesso em: 20 julho 2012.

Résumé: La représentation des Noirs brésiliens dans le théâtre brésilien moderne a presque toujours été influencée par l'idée que les noirs ne sont pas confrontés à des problèmes susceptibles d'entraver réelement leur développement spirituel, physique et matériel, les Noirs étant supposés vivre dans une sorte de "paradis racial". En 1948, cette représentation des Noirs évolue, en particulier avec Ange noir, de Nelson Rodrigues. Cet article examine la façon dont le dramaturge traite le Noir dans ce drame.

Mots-clefs: drame brésilien ; Nelson Rodrigues ; personnage nègre. 